\section{Creation of an artificial} intelligence system for analysis of theoretical

\section{Current-Voltage Curves}

\author{
AV Kovalenko ${ }^{1 *}$ and MKh Urtenov² \\ 'Docent, Doctor of Economics, Vice head, Intelligent Information Systems, Kuban State University, \\ Russia \\ 2Professor, Doctor of Physics and Mathematics Head, Applied Mathematics, Kuban State University, \\ Russia
}

Received: 09 June, 2020

Accepted: 18 June, 2020

Published: 19 June, 2020

*Corresponding author: AV Kovalenko, Docent, Doctor of Economics, Vice head, Intelligent Information Systems, Kuban State University, Russia, Tel: Tel: +7918-98-00003; E-mail: savanna-05@mail.ru

Keywords: Neural networks; Deep machine learning; Electro-membrane systems; Current-voltage characteristics; Computer simulation

https://www.peertechz.com

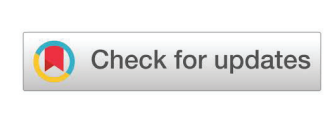

\title{
Abstract
}

We have developed the "Deep learning for CVC 0.1 " software package, which contains databases and knowledge bases of theoretical Current-Voltage Curve (CVC) using the method of deep machine learning (Deep learning). The developed software package allows you to simulate mass transfer in Electromembrane Systems (EMS), which has a single interface with a built-in help system, analysis and synthesis of current-voltage characteristics. The software package was implemented using the software platform for computer modeling of physical processes COMSOL Multiphysics 5.5 and the application development environment COMSOL Multiphysics Application Builder, Java, Python, using the libraries OpenCV, TensorFlow, Keras.

\section{Introduction}

The CVC (current-voltage characteristic, I-V characteristic) is the most important integral characteristic of transfer processes in electromembrane systems. The study of experimental CVC. Shows the complex, unsteady, and unstable behavior of the CVC. However, a theoretical study of the CVC has not yet been carried out. This is due to the fact that, on the one hand, to calculate one I-V characteristic, it is required (indicate the time) and therefore costs (hundreds of thousands of dollars to indicate how much). On the other hand, it is necessary to use methods that adequately reflect the unsteady and unstable behavior of the CVC in time. For the first time, we were able to solve these problems in a complex using a specially created system of artificial intelligence.

\section{Used methods and results}

The software package (program) "Deep learning for CVC 0.1 " created by us allows you to get images that simulate the studied processes in the EMC [1-4], calculate all relevant characteristics, including the CVC [5-8], generate reports, and get an animated interpretation of the process studied in time.

The program "Deep learning for CVC 0.1" (Figure 1), containing databases and knowledge bases of theoretical current-voltage characteristics for deep machine learning, allows you to select specific sections of the CVC, for example, the section of the beginning of electroconvection [2-8] at the Cation Exchange Membrane (CEM) which begins with dfikom (beginning) and ends with dfiaom (the beginning of electroconvection at the Anion Exchange Membrane (AEM)), the plot of the beginning of electroconvection at the AOM, the site of the beginning of the interaction of electroconvection vortices at the CEM and AEM, and others. In these areas, the software package allows you to conduct Fourier and Wavelet analyses, identify the trend, subtract the CVC from the trend, calculate the fluctuations amplitude, determine the main and accompanying fluctuation frequencies, use the results to record the "restored" CVC (I - V characteristic) and compare it with the real one, find the dependence of the CVC on the parameters of the problem with the approximation condition. 


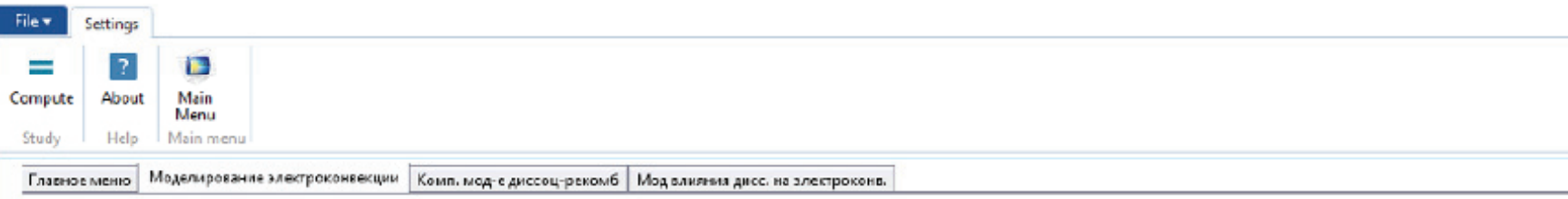

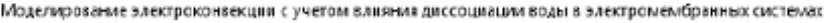

\begin{tabular}{|c|c|c|}
\hline Типичнея осорест:: & $8 \mathrm{e} \cdot 4$ & \\
\hline Начальная концентрация: & 0.010 & \\
\hline Козффициенг Аиффугия квтиона: & $1.35 \times 7 e-9\left[\mathrm{~m}^{\wedge} 2 / s\right]$ & \\
\hline Козффициент диффудия аниома: & $\left.2,03^{\wedge}\right] \mathrm{e}-9\left[\mathrm{~m}^{\wedge} \mathrm{2} / \mathrm{s}\right]$ & \\
\hline D3: & $5.23^{*} 1 \mathrm{e}-9\left[\mathrm{~m}^{\wedge} 2 / \mathrm{s}\right]$ & \\
\hline 04: & $9.34^{*} 7 \mathrm{e}-5\left[\mathrm{~m}^{\wedge} 2 / \mathrm{s}\right]$ & \\
\hline di: & 0.0001 & \\
\hline d11: & 0.0050001 & \\
\hline Ночальнал концентрация дия ионов третьего сорта: & $2^{2} 0.0000001\left[\mathrm{~mol}^{\prime} \mathrm{m}^{\wedge} 3\right]$ & \\
\hline Шприна канвла: & $0.5 * 1 \mathrm{e}-3[\mathrm{~m}]$ & \\
\hline Алина рассоизтриелемой с Слисти: & $4^{x} \mathrm{H}$ & \\
\hline
\end{tabular}

\begin{tabular}{|l|l|l|l|l|l|l|l|l|}
\hline C1 & C2 & C3 & Линии токажиакости & Плотность2 & Ппотность & Падение потенцмала & |x & y \\
\hline
\end{tabular}

$4^{x} \mathrm{H}$

m
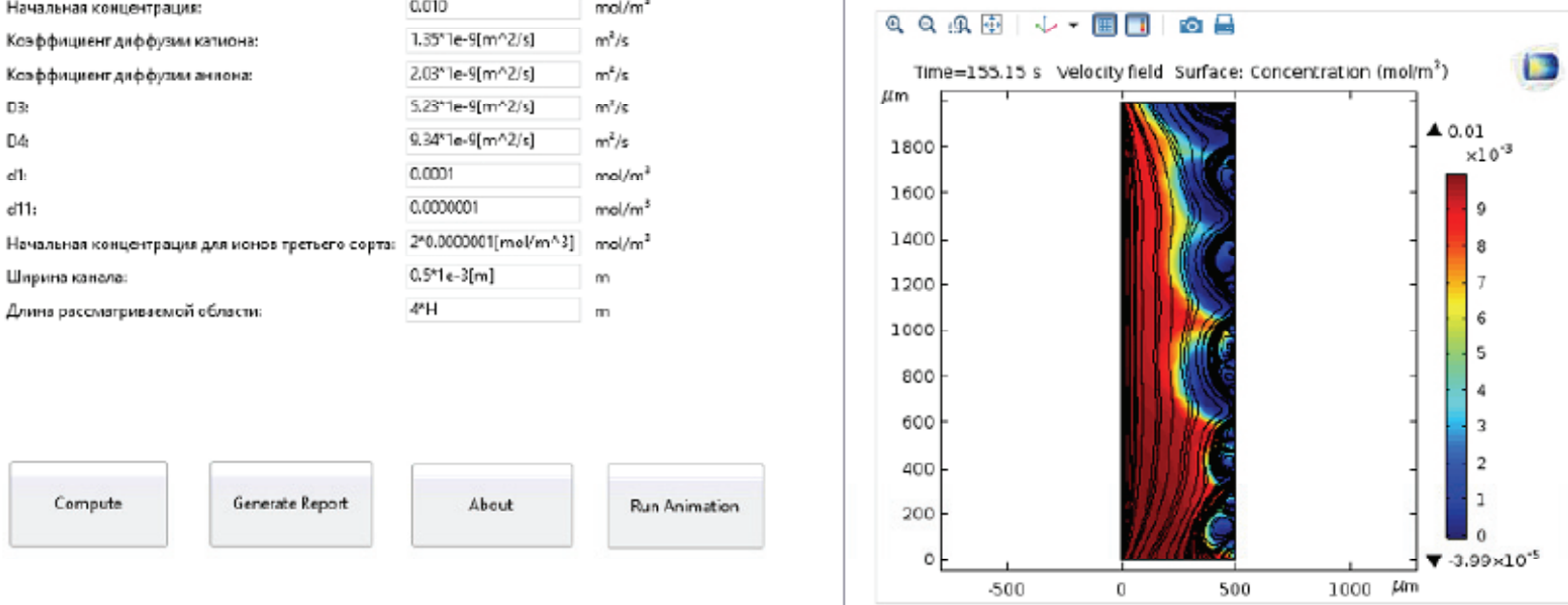

Figure 1: The window of the created application with the open tab "Modeling electroconvection".

Moreover, the created program allows one to calculating critical currents (Ikom, Iaom, etc.), Hurst indicators for each section of the current - voltage characteristic, Lyapunov, associated frequencies, vibration amplitudes, and tilt angles in the first and second sections.

The artificial intelligence systems created under the project, for example, Deep Learning Neural Networks, allow you to recreate the CVC (I - V characteristics) according to specified parameters and approximate for a given time interval, recognize critical values, predict mass transfer in EMC subject to modification of the main system parameters.

During the project implementation, convolutional neural networks (CNNs) trained by the classical method of back propagation of errors, deep controlled recurrent neural networks (Depth Gated RNN) with custom behavior, including longterm short-memory networks (LSTM), as well as multilayer perceptron networks with dozens of tens hidden layers and hundreds of elements in them, trained by the methods of gradient descent, Levenberg-Markar and others with crossbatch state conservation (Cross-Batch Statefulness).

\section{Conclusion}

The developed app "Deep learning for CVC 0.1" is a flexible system, a scientific toolkit for conducting new scientific research in the field of application of artificial intelligence methods, which allows to obtain 2D, 3D images simulating these processes, including calculation and visualization of all physicochemical characteristics, adjustment whose parameters allows us to obtain a solution that meets the actual conditions of the experiments. For all created programs that make up the software package, there are certificates of state registration [8].

\section{Funding}

The reported study was funded by RFBR according to the research project № 19-08-00252 A.

\section{References}

1. Do you use multiphysics simulation for analysis or innovation?. Link: https://bit.ly/2N7wwz9

2. Pismenskiy A, Urtenov M, Kovalenko A, Mareev S (2015) Electrodialysis desalination process in conditions of mixed convection. Desalination and Water Treatment 56: 3211-3213. Link: https://bit.ly/3hG2WyH

3. Kovalenko AV, Yzdenova AM, Sukhinov Al, Chubyr NO, Urtenov MKh (2019) Simulation of galvanic dynamic mode in membrane hydrocleaning systems taking into account space charge. AIP Conference Proceedings Proceedings of XV International scientific-technical conference "Dynamics of technical systems" (DTS-2019): electronic edition. C. 050021. Link: https://bit.ly/2YK69VB

4. Urtenov MKh, Kovalenko AV, Sukhinov Al, Chubyr NO, Gudza VA (2019) Model and numerical experiment for calculating the theoretical current-voltage characteristic in electro-membrane systems. IOP Conference Series: Materials Science and Engineering. Link: https://bit.ly/2USroml

5. Nikonenko VV, Kovalenko AV, Urtenov MK, Pismenskaya ND, Han J, et al. (2014) Desalination at overlimiting currents: state-of-the-art and perspectives. Desalination 342: 85-106. Link: https://bit.ly/30RTum0

6. Urtenov MK, Uzdenova AM, Kovalenko AV, Nikonenko VV, Pismenskaya ND, et al. (2013) Basic mathematical model of overlimiting transfer enhanced by 
electroconvection in flow-through electrodialysis membrane cells. Journal of Membrane Science 447: 190-202. Link: https://bit.ly/3ee8y10

7. Nikonenko VV, Mareev SA, Pis'menskaya ND, Uzdenova AM, Kovalenko AV et al. (2017) Effect of electroconvection and its use in intensifying the mass transfer in electrodialysis (Review). Russ J Electrochem 53: 1122-1144. Link: https://bit.ly/2URI9OT
8. Nikonenko VV, Vasil'eva VI, Akberova EM, Uzdenova AM, Urtenov AV, et al. (2016) Pourcelly Competition between diffusion and electroconvection at an ion-selective surface in intensive current regimes. Advances Colloid Interface Science 235: 233-246 Link: https://bit.ly/2YPzFZQ
Discover a bigger Impact and Visibility of your article publication with

\section{Peertechz Publications}

\section{Highlights}

* Signatory publisher of ORCID

* Signatory Publisher of DORA (San Francisco Declaration on Research Assessment)

- Articles archived in worlds' renowned service providers such as Portico, CNKI, AGRIS, TDNet, Base (Bielefeld University Library), CrossRef, Scilit, J-Gate etc.

* Journals indexed in ICMJE, SHERPA/ROMEO, Google Scholar etc.

* OAI-PMH (Open Archives Initiative Protocol for Metadata Harvesting)

* Dedicated Editorial Board for every journal

* Accurate and rapid peer-review process

* Increased citations of published articles through promotions

* Reduced timeline for article publication

Submit your articles and experience a new surge in publication services (https://www.peertechz.com/submission).

Peertechz journals wishes everlasting success in your every endeavours.

Copyright: @ 2020 Kovalenko AV, et al. This is an open-access article distributed under the terms of the Creative Commons Attribution License, which permits unrestricted use, distribution, and reproduction in any medium, provided the original author and source are credited. 